\title{
Six decades of publication performances and scientific maps on sports nutrition
}

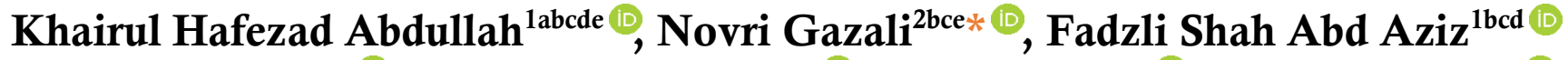

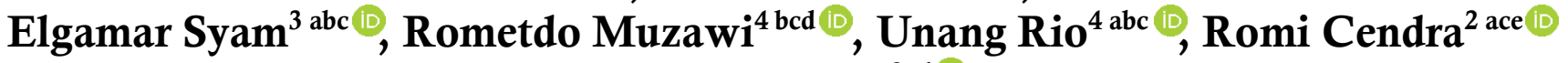 \\ Novia Nazirun ${ }^{2 a d}$ (1)
}

\author{
Universiti Utara Malaysia, Malaysia ${ }^{1}$ \\ Universitas Islam Riau, Indonesia ${ }^{2}$ \\ Universitas Islam Kuantan Singingi, Indonesia ${ }^{3}$ \\ STMIK Amik Riau, Indonesia ${ }^{4}$
}

Received: 19 November 2021; Accepted 29 December 2021; Published 01 February 2022

Ed 2022; 7(1): 1-22

\begin{abstract}
A well-balanced diet is essential for individuals, particularly athletes, because it improves overall health by supplying energy besides repairing and replacing damaged cells. A well-balanced diet is also benefitting athletes to fuel their bodies before, during, and after training. This study aims to examine the intellectual structure of sports nutrition research using bibliometric measures from 1959 to 2021 based on the Scopus database. The study was investigated using SciMAT software, which employed keyword co-occurrence analysis to extract performance and scientific output vis-à-vis critical topics or themes in sports nutrition. The findings indicated that sports nutrition possesses enormous potential and growth potential. The most prevalent themes in this research area are trace elements, exercise, questionnaire, carbohydrate, and adolescent. Also, this study put up to analysing sports nutrition in countless fields, assisting in understanding its intellectual structure. Future researchers could use this data to identify the focus of awareness and make decisions in multiple ways. This study has a few limitations: 1) the researchers' interpretation of the themes in this study was grounded on their knowledge; 2) this study only considered publication records from the Scopus database, and some sports nutrition publications may not have been included; and 3) if additional databases, such as Google Scholar, Microsoft Academics, or Dimensions, were accessed, the subject area may have shifted. The findings of this study should be accepted as a single evidence-based framework for developing future studies on sports nutrition research that will benefit researchers, practitioners, and policymakers.
\end{abstract}

Keywords: Sports nutrition; publication performances; scientific maps; scopus database; bibliometric

https://doi.org/10.25299/sportarea.2022.vol7(1).8126

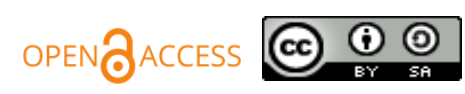

Copyright @ 2022 Khairul Hafezad Abdullah, Novri Gazali, Fadzli Shah Abd Aziz, Elgamar Syam, Rometdo Muzawi, Unang Rio, Romi Cendra, Novia Nazirun

Corresponding Author: Novri Gazali, Department of Physical Education Health and Recreation, Faculty of Teacher Training and Education, Universitas Islam Riau, Pekanbaru, Indonesia

Email: novri.gazali@edu.uir.ac.id

How to Cite: Abdullah, K. H., Gazali, N., Abd Aziz, F. S., Syam, E., Muzawi, R., Rio, U., Cendra, R., \& Nazirun, N. (2022). Six decades of publication performances and scientific maps on sports nutrition. Journal Sport Area, 7(1), 1-22. https://doi.org/10.25299/sportarea.2022.vol7(1).8126

Authors' Contribution: a - Study Design; b - Data Collection; c - Statistical Analysis; d - Manuscript Preparation; e - Funds Collection 


\section{INTRODUCTION}

A well-balanced diet is crucial to every individual, especially athletes. It boosts general health by supplying the body with energy besides repairing and replacing cells that have been harmed. Sports nutritionists agree that a well-balanced diet is essential for athletes who want to keep their bodies wellfuelled before, during, and after training (Arenas-Jal et al., 2020; Ravindra et al., 2020). In addition, it also aids in the maintenance of fitness, toughness, and endurance during the competition or any sports events (Potgieter, 2013). Previous studies noted that a well-balanced diet and sports nutrition fascinated significant attention in sport and exercise research (Devlin \& Belski, 2015; Gavrilova et al., 2020; Potgieter, 2013). Sports nutrition is closely related to clinical, medical, health, biomedical, and sport sciences, which involve disseminating knowledge about physical activity, health, metabolism, body composition, diseases, training, injuries, rehabilitation, and performance (Kiss et al., 2021). Accordingly, specific aspects of sports nutrition will benefit from dietary guidelines that meet athletes' nutritional needs (Burke \& Read, 1989). Insufficient sports nutrition will likely reduce acute performance, training effectiveness, and recovery (Burke \& King, 2012).

Athletes' nutritional requirements differ from those of non-athletes. Consequently, to optimise fitness and performance, athletes' nutritional intake should be calculated based on their energy requirements and the total calorie content of the nutrient (Nunes et al., 2018). Also, it was evident that eating the right foods and beverages in the right quantities and at precise times is critical for recharging the body and improving athletic performance (Guest et al., 2019). Furthermore, nutritional requirements differ before, during, and after training depending on intensity, workout type, body composition, and weather (Burke et al., 2006). Glycogen synthesis and breakdown occur before exercise (Ravindra et al., 2020). Ravindra et al. (2020) stated that rapid exogenous glucose absorption, insulin release, electrolyte replacement, and fluid retention are vital during exercise. Nevertheless, they mentioned that during the post-training phase, rapid amino acid absorption, protein synthesis, muscle and tendon repair, inflammation reduction, and oxidative stress reduction are essential. Hence, nutritional sources that could assist athletes' metabolic needs should be considered.

Athletes utilise nutritional supplements to boost performance, speed recovery, prevent vitamin deficiencies, and preserve overall health. Aljaloud and Ibrahim (2013) found $93.30 \%$ of athletes in Saudi Arabia consumed various dietary supplements throughout the season, $43.80 \%$ used up nutritional supplements for performance, and $32.60 \%$ believed in the health advantages of the nutritional supplements. Bailey et al. (2011) discovered that half of the adult population in the United States uses some dietary supplement; while regional, cultural, and economic differences exist, a similar prevalence is likely in many other countries. Furthermore, Fennell (2004) stated that athletes express a variety of reasons for their nutritional supplement selections and products that meet the supplement criteria conceivably play various roles within the athlete's performance strategy. Based on these three prior studies, athletes' use of nutritional supplements at all levels of competition reflects the widespread availability of these products in society. Hence, sports nutrition knowledge is critical for athletes to select a diet to optimise sports performance.

Sports nutrition comprises powders, beverages, and pills purchased at a pharmacy or grocery store is classified as a dietary supplement, ergogenic acid, and sports food (Molinero \& Márquez, 2009). Athletes use nutritional supplements on a widespread and acknowledged basis, with a high prevalence of use and various product types and brands (Burke et al., 2006). Also, numerous studies have established that athletes participating in multiple sports have more important nutritional requirements than the general population due to the nature of their physical activity, metabolic demands, and physical growth (Kaur \& Nat, 2016). Due to the industry's lack of oversight, many supplement items of doubtful value, composition, and quality are currently available worldwide. Numerous dietary supplements contain chemicals that are either restricted in sports or linked to severe morbidity and mortality (Mazzeo et al., 2013). Supplements and sports meals are vital in light of the findings that certain products can enhance performance (Amatori et al., 2020).

In recognition of the importance of this research area, this study will use bibliometric analysis to provide a broader view of sports nutrition. The term bibliometric is derived from the concepts Biblio, which is denoted as books and metrics related to measuring. Bibliometrics is the study or quantification of books or 
other publications using metadata from multiple databases. Bibliometric analysis currently includes Google Scholar, Dimensions, Microsoft Academic, Scopus, PubMed, and Web of Science. Even so, Scopus, Web of Science, and PubMed have remained the most popular databases within academic circles. In the area of sports science research, bibliometric analysis has been used to determine research trends and to identify publications with a high impact in the areas of sport management (Ciomaga, 2013), sports innovation (Ferreira et al., 2020), sports tourism and sustainability (Jiménez-García et al., 2020), sports economics (Santos \& García, 2011), sport and exercise psychology (Lindahl et al., 2015), and physical education (Gazali et al., 2021; Hanief et al., 2021). There has been little analysis of sport nutrition trends, performance, and scientific production. Thus, the bibliometric analysis in this current study is based on co-occurrence analysis of keywords from the SciMAT software. It is aimed to analyse sports nutrition's performance and scientific production and the most critical themes within this field study.

\section{METHOD}

\section{Data Retrieval}

In this study, the Scopus database was used as the medium for data assortment. Scopus database was chosen over PubMed and Web of Science because its index is ampler. Additionally, the database includes relevant and reputable research sources for certain scholars and their works. On November $6^{\text {th }}, 2021$, the term "sports nutrition" was searched to repossess all pertinent metadata in the Scopus database utilising the TITLE-ABS-KEY structure, as specified in Figure 1. A modified version of the flow diagram proposed by Moher et al. (2009) has been used to illustrate the process in this study. By default, the Scopus database includes popular variation spellings for British and American English and the majority of plural forms; as a result, the search process for validated data sets may be streamlined.

The metadata for the search keyword revealed 1411 publications dating back to 1959, of which two publications have been indexed in the Scopus database. The publications included journal articles, books, book series, conference proceedings, and trade journals. This study identified the journal article as the primary document source popularly among previous researchers, accounting for 1238 total publications. According to the list of retrieved metadata, there are 1303 academic works written in English. Besides, 547 open-access documents were deposited in the database that readers and researchers could access to obtain relevant articles to enrich their information. Finally, the retrieved data were processed using Microsoft Excel, Publish or Perish, and SciMAT to evaluate and analyse sports nutrition's performance and scientific output. Notably, both strategies work in tandem to generate meaningful results that will benefit future researchers and readers.

\section{Data Exploration}

The intellectual structure of sports nutrition was extracted using bibliometric analysis with SciMAT software. SciMAT was chosen for its flexibility in generating and visualising bibliometric networks; it also includes numerous preprocessing techniques for troubleshooting raw data collected from databases (PauleVianez et al., 2020). In addition, the bibliometric examination of scientific maps enables tracking a scientific field's structure, evolution, and critical intervening agents from scientific documents (Cobo et al., 2011). The keywords were chosen as the unit of analysis in this study to determine their relationship using a cooccurrence analysis to discover a research area's main themes based on conceptual and cognitive features. Keyword co-occurrence transpired when two keywords appeared simultaneously in the same document.

Normalising the bibliometric network built on keyword co-occurrence relationships is necessary to obtain meaningful information from a research area via scientific mapping. Keyword relations with low frequency but high co-occurrence are more significant than the keyword with high frequency but low co-occurrence (Cobo et al., 2012). Clustering techniques separate the network into distinct subsets with nodes closely related to one another (clusters) but not to the rest. This study chooses a clustering technique based on simple centres since it has the advantage of automatically returning clusters labelled with the group's most central node (Cobo et al., 2012). Thus, each topic will be signified by various nodes (keywords). The size of 
the sphere of each node is proportional to the number of documents associated with a said keyword, and the thickness of the lines between two nodes is proportional to its index equivalence.

The various clusters are displayed on the well-known strategic diagram to assess each topic's position within the study domain. The strategic diagram enables topics or themes to be positioned according to their centrality (x-axis) and density (y-axis). The centrality metric indicates an issue's (topics or themes) interaction with other issues (topics or themes); the density metric quantifies a subject's internal cohesion (Cobo et al., 2011).

According to Cobo et al. (2011), the various themes in the strategic diagram can be classified into the following categories:

1. Themes-motor (in the first sequence or the upper right) referred to high centrality and density themes. They are well-developed and have become essential themes in the research area.

2. Very specialised and peripheral themes (in the second sequence or the upper left) is related to the topics or themes with low centrality. Still, high density is a highly developed topic but isolated from the rest.

3. Emerging or disappearing themes (in the third sequence or the lower left) is denotes the topics or themes with low centrality and density. They are underdeveloped and marginal in the research area.

4. Basic or transversal themes (in the fourth sequence or the lower right) are concerned about topics with high centrality but low density. So, they are closely related to the rest but little developed in themselves.
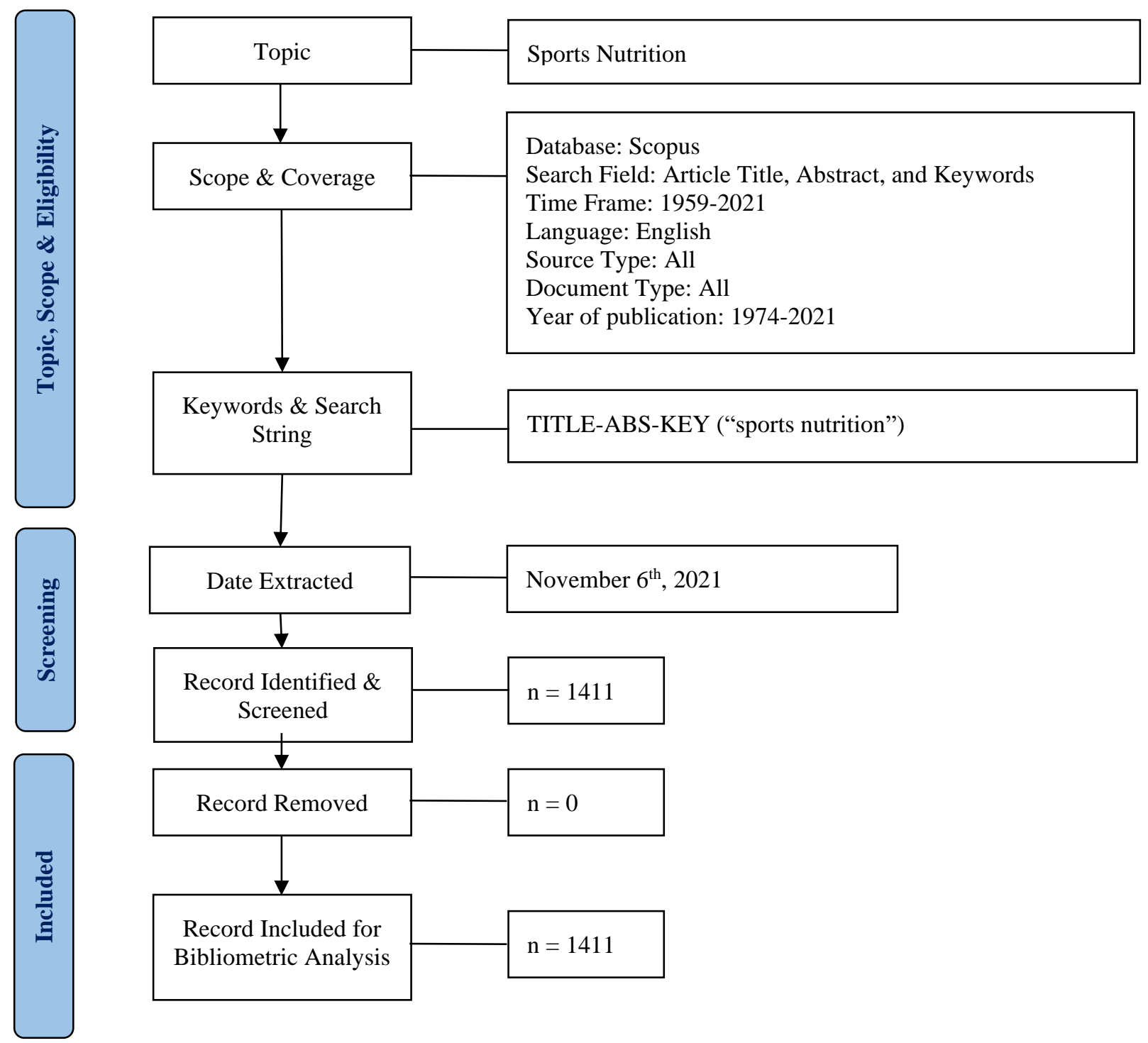

Figure 1. Flow Diagram of the Search Strategy 


\section{RESULTS AND DISCUSSION}

\section{Publication Performances}

Examining the evolution of publications enables future researchers and readers to discover the progress and popularity of the research on sports nutrition over time. Figure 2 depicts the total annual number of sports nutrition publications from 1959 to 2021, with a peak publication growth of 175 in 2020. The number of publications per year was less than 20 in the first four decades, from 1959 to 2005. Low research productivity during the early stages can sometimes be attributed to the researchers' lack of funding. According to Miyaki and Okajima (2018), funding increases are indeed interrelated with research productivity.

The number of publications began to rise in 2006, with 28 or more publications per year, and peaked in 2015, with 89. The number of publications dropped to 65 in 2016, then increased to 91 and 119 in 2017 and 2018, respectively, before falling to 114 in 2019. The year with the highest productivity was 2020, while the lowest productivity years were 1969, 1976, 1980, 1981, 1985, and 1986, with only one publication consistently. The growing number of sports nutrition publications attests to sports nutrition as a dynamic field of science and practice that thrives in terms of the breadth of support it provides to athletes and the strength of evidence that underpins its recommendations (Thomas et al., 2016). For the year 2021, a total of 154 publications have been retrieved through November. As a result, some publications, particularly those published in December, have not been deposited in the Scopus database.

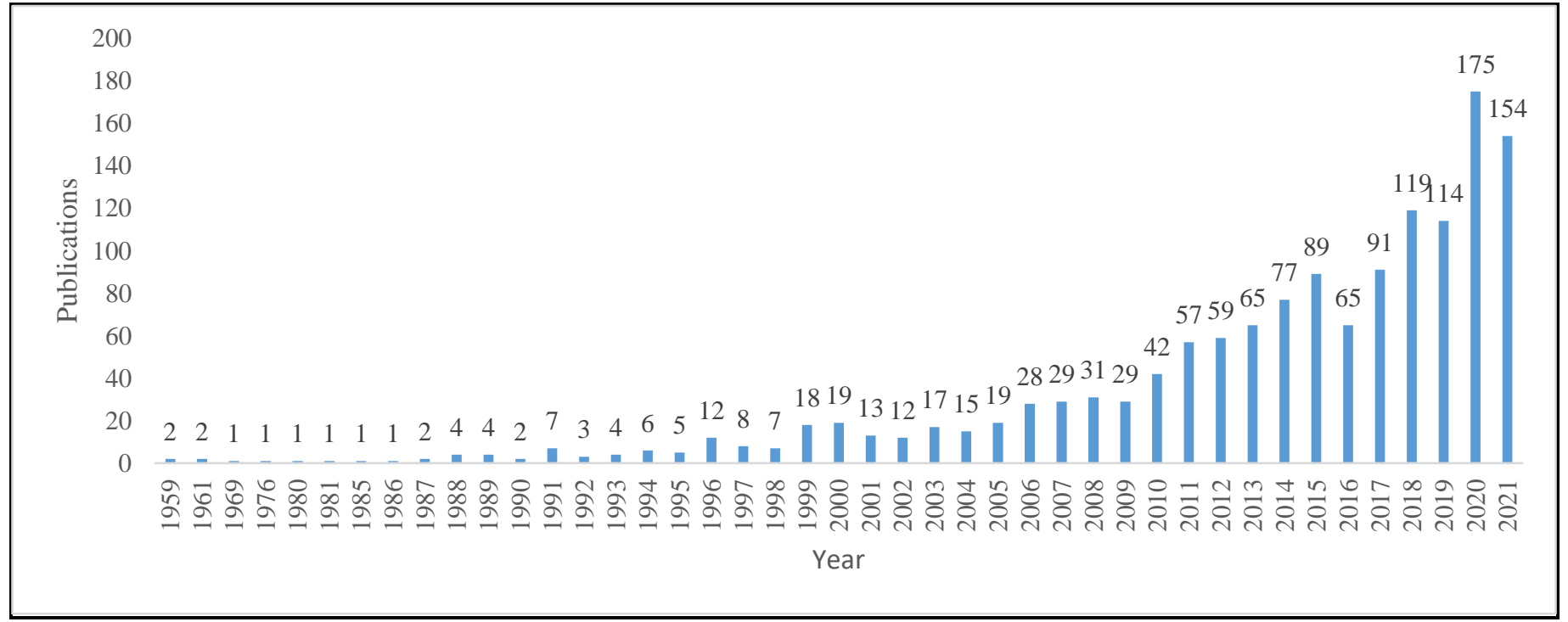

Figure 2. The Evolution of Sports Nutrition Publications

The top five authors who have published at least 18 articles on sports nutrition in the last 62 years (19592021) are listed in Table 1. Burke, L. M., a well-known author, ranked first with 97 publications. Castell, L. M., and Stear, S. J. tied for second place with 52 publications. Kreider, R. B. came in third place with 28 publications. Antonio, J. was ranked fourth with 25 publications. Campbell, B. I., takes fifth place with 18 publications. This data will provide future researchers and readers with well-known sports nutrition authors or experts published widely.

Table 1. The List of Top Five Authors Published Articles on Sports Nutrition

\begin{tabular}{ccc}
\hline Rank & Authors & Publications \\
\hline 1 & Burke, L. M. & 97 \\
2 & Castell, L. M. & 52 \\
2 & Stear, S. J. & 52 \\
3 & Kreider, R. B. & 28 \\
4 & Antonio, J. & 25 \\
5 & Campbell, B. I. & 18 \\
\hline
\end{tabular}


This study used citation metrics via Publish or Perish (POP) software to determine which publications had the most significant impact and performance. The results indicate that 19940 citations have been made to 1411 documents over 62 years, averaging 321.61 citations per year. The dataset's highly cited sports nutrition publications were analysed further to identify the most influential works in this field over the last six decades, and it is likely that articles on this subject must be cited. Future researchers and readers will be able to locate pertinent papers for their research through this analysis.

Table 2 summarises the top ten most frequently cited publications in the field of sports nutrition research. An article was written by the American College of Sports Medicine in 2016, published by Medicine and Science in Sports and Exercise entitled "Nutrition and Athletic Performance", received a total of 494 citations, with a rate of citation per year 98.8 until this bibliometric is performed. This article discusses the Academy of Nutrition and Dietetics, Dietitians of Canada's, and American College of Sports Medicine's positions on nutrition factors known to affect athletic performance and emerging trends in sports nutrition. According to the article, athletes should obtain preferences on the nutritional supplement from a registered dietitian or nutritionist for developing their customised nutrition plan. Also, the paper had specified that a Certified Specialist in Sports Dietetics is a registered dietitian or nutritionist and a credentialed sports nutrition expert in the United States and Canada.

Table 2. The List of Top Ten Highly Cited Publications on Sports Nutrition

\begin{tabular}{ccccccc} 
Rank & Cites & Cites Per Year & Authors & Title & Year & Source \\
\hline 1 & 494 & 98.8 & $\begin{array}{c}\text { Thomas, D Travis } \\
\text { Erdman, Kelly Anne } \\
\text { Burke, Louise M }\end{array}$ & $\begin{array}{c}\text { Nutrition and Athletic } \\
\text { Performance }\end{array}$ & 2016 & $\begin{array}{c}\text { Medicine and Science } \\
\text { in Sports and Exercise }\end{array}$ \\
\hline
\end{tabular}

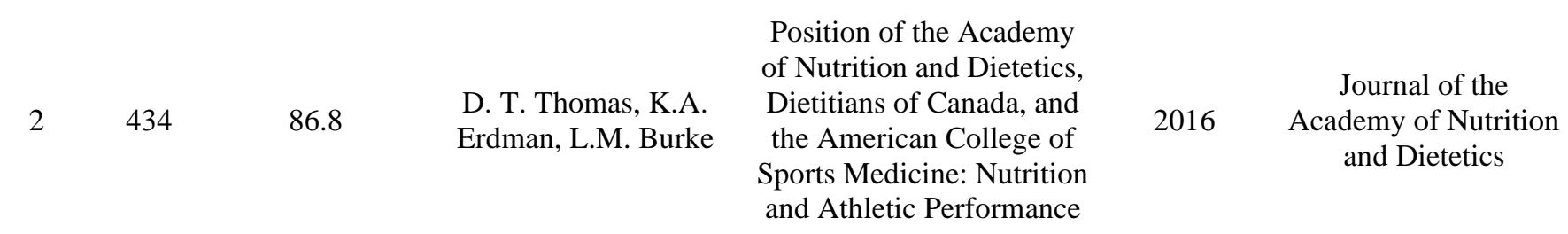

\begin{tabular}{|c|c|c|c|c|c|c|}
\hline 3 & 351 & 15.26 & $\begin{array}{l}\text { R.B. Kreider, M. } \\
\text { Ferreira, M. Wilson, } \\
\text { P. Grindstaff, S. } \\
\text { Plisk, J. Reinardy, E. } \\
\text { Cantler, A.L. Almada }\end{array}$ & $\begin{array}{c}\text { Effects of creatine } \\
\text { supplementation on body } \\
\text { composition, strength, and } \\
\text { sprint performance }\end{array}$ & 1998 & $\begin{array}{l}\text { Medicine and Science } \\
\text { in Sports and Exercise }\end{array}$ \\
\hline
\end{tabular}

$4290 \quad 16.11 \quad$ E. Ha, M.B. Zemel $\begin{gathered}\text { Functional properties of } \\ \text { whey, whey components, } \\ \text { and essential amino acids: } \\ \text { Mechanisms underlying } \\ \text { health benefits for active } \\ \text { people (Review) }\end{gathered} \quad 2003 \quad \begin{gathered}\text { Journal of Nutritional } \\ \text { Biochemistry }\end{gathered}$

\begin{tabular}{|c|c|c|c|c|c|c|}
\hline 5 & 282 & 25.64 & $\begin{array}{l}\text { E.R. Goldstein, T. } \\
\text { Ziegenfuss, D. } \\
\text { Kalman, R. Kreider, } \\
\text { B. Campbell, C. } \\
\text { Wilborn, L. Taylor, } \\
\text { D. Willoughby, J. } \\
\text { Stout, B.S. Graves, } \\
\text { R. Wildman, J.L. Ivy, } \\
\text { M. Spano, A.E. } \\
\text { Smith, J. Antonio }\end{array}$ & $\begin{array}{l}\text { International society of } \\
\text { sports nutrition position } \\
\text { stand: Caffeine and } \\
\text { performance }\end{array}$ & 2010 & $\begin{array}{l}\text { Journal of the } \\
\text { International Society of } \\
\text { Sports Nutrition }\end{array}$ \\
\hline
\end{tabular}




\begin{tabular}{|c|c|c|c|c|c|c|}
\hline Rank & Cites & Cites Per Year & Authors & Title & Year & Source \\
\hline 6 & 248 & 22.55 & $\begin{array}{l}\text { R.B. Kreider, C.D. } \\
\text { Wilborn, L. Taylor, } \\
\text { B. Campbell, A.L. } \\
\text { Almada, R. Collins, } \\
\text { M. Cooke, C.P. } \\
\text { Earnest, M. } \\
\text { Greenwood, D.S. } \\
\text { Kalman, C.M. } \\
\text { Kerksick, S.M. } \\
\text { Kleiner, B. Leutholtz, } \\
\text { H. Lopez, L.M. } \\
\text { Lowery, R. Mendel, } \\
\text { A. Smith, M. Spano, } \\
\text { R. Wildman, D.S. } \\
\text { Willoughby, T.N. } \\
\text { Ziegenfuss, J. } \\
\text { Antonio }\end{array}$ & $\begin{array}{l}\text { ISSN exercise and sport } \\
\text { nutrition review: Research } \\
\text { and recommendations }\end{array}$ & 2010 & $\begin{array}{c}\text { Journal of the } \\
\text { International Society of } \\
\text { Sports Nutrition }\end{array}$ \\
\hline 7 & 223 & 55.75 & $\begin{array}{c}\text { R. Jäger, C.M. } \\
\text { Kerksick, B.I. } \\
\text { Campbell, P.J. Cribb, } \\
\text { S.D. Wells, T.M. } \\
\text { Skwiat, M. Purpura, } \\
\text { T.N. Ziegenfuss, } \\
\text { A.A. Ferrando, S.M. } \\
\text { Arent, A.E. Smith- } \\
\text { Ryan, J.R. Stout, P.J. } \\
\text { Arciero, M.J. } \\
\text { Ormsbee, L.W. } \\
\text { Taylor, C.D. } \\
\text { Wilborn, D.S. } \\
\text { Kalman, R.B. } \\
\text { Kreider, D.S. } \\
\text { Willoughby, J.R. } \\
\text { Hoffman, J.L. } \\
\text { Krzykowski, J. } \\
\text { Antonio }\end{array}$ & $\begin{array}{l}\text { International Society of } \\
\text { Sports Nutrition Position } \\
\text { Stand: Protein and exercise }\end{array}$ & 2017 & $\begin{array}{l}\text { Journal of the } \\
\text { International Society of } \\
\text { Sports Nutrition }\end{array}$ \\
\hline 8 & 213 & 21.3 & $\begin{array}{c}\text { A.B. Loucks, B. } \\
\text { Kiens, H.H. Wright }\end{array}$ & $\begin{array}{c}\text { Energy availability in } \\
\text { athletes }\end{array}$ & 2011 & $\begin{array}{c}\text { Journal of Sports } \\
\text { Sciences }\end{array}$ \\
\hline 9 & 197 & 28.14 & A.M. Jones & $\begin{array}{c}\text { Dietary nitrate } \\
\text { supplementation and } \\
\text { exercise performance }\end{array}$ & 2014 & Sports Medicine \\
\hline 10 & 191 & 63.67 & $\begin{array}{l}\text { C.M. Kerksick, C.D. } \\
\text { Wilborn, M.D. } \\
\text { Roberts, A. Smith- } \\
\text { Ryan, S.M. Kleiner, } \\
\text { R. Jäger, R. Collins, } \\
\text { M. Cooke, J.N. } \\
\text { Davis, E. Galvan, M. } \\
\text { Greenwood, L.M. } \\
\text { Lowery, R. Wildman, } \\
\text { J. Antonio, R.B. } \\
\text { Kreider }\end{array}$ & $\begin{array}{l}\text { ISSN exercise \& sports } \\
\text { nutrition review update: } \\
\text { Research \& } \\
\text { recommendations }\end{array}$ & 2018 & $\begin{array}{l}\text { Journal of the } \\
\text { International Society of } \\
\text { Sports Nutrition }\end{array}$ \\
\hline
\end{tabular}

The source title is typically the title of a journal, a conference proceeding, or a book. This study recognised 24 source titles with at least ten publications within six decades. According to Table 3, the most active source title from the documents retrieved is the International Journal of Sport Nutrition and Exercise Metabolism, which has 116 publications (10.03\%), followed by the Nutrients, which has 103 publications 
(8.90\%), and the Journal of The International Society of Sports Nutrition, which has 68 publications $(5.88 \%)$. Analysing the most active source titles enables future researchers or readers to submit their sports nutrition articles via the provided list, as shown in Table 3. Also, the top ten active source titles educate future researchers and readers on sports nutrition better. The educational value of source titles goes beyond communication and documentation. The authors will help researchers or readers reflect on what they read from the best writing sources and express their thoughts to analyse the articles published in those sources.

Table 3. The List of Active Source Titles on Sports Nutrition with a Minimum Ten Publications

\begin{tabular}{|c|c|c|}
\hline Source Titles & Publications & Percentages $(\%)$ \\
\hline International Journal of Sport Nutrition and Exercise Metabolism & 116 & 10.03 \\
\hline Nutrients & 103 & 8.90 \\
\hline Journal of The International Society of Sports Nutrition & 68 & 5.88 \\
\hline British Journal of Sports Medicine & 56 & 4.84 \\
\hline Nutrition and Enhanced Sports Performance Muscle Building Endurance and Strength & 29 & 2.51 \\
\hline Sports & 24 & 2.07 \\
\hline Journal of Sports Sciences & 22 & 1.90 \\
\hline Food Manufacture & 21 & 1.82 \\
\hline Agro Food Industry Hi Tech & 20 & 1.73 \\
\hline International Journal of Sport Nutrition & 19 & 1.64 \\
\hline Sports Medicine & 19 & 1.64 \\
\hline Journal of The American College of Nutrition & 18 & 1.56 \\
\hline Journal of Strength and Conditioning Research & 17 & 1.47 \\
\hline Applied Physiology Nutrition and Metabolism & 16 & 1.38 \\
\hline Advance Journal of Food Science and Technology & 14 & 1.21 \\
\hline Deutsche Zeitschrift Fur Sportmedizin & 14 & 1.21 \\
\hline Strength and Conditioning Journal & 14 & 1.21 \\
\hline Voprosy Pitaniia & 14 & 1.21 \\
\hline Progress in Nutrition & 13 & 1.12 \\
\hline International Journal of Environmental Research and Public Health & 12 & 1.04 \\
\hline Journal of Sports Science and Medicine & 11 & 0.95 \\
\hline Journal of The American Dietetic Association & 11 & 0.95 \\
\hline European Journal of Sport Science & 10 & 0.86 \\
\hline Frontiers in Nutrition & 10 & 0.86 \\
\hline
\end{tabular}

\section{Creation and Analysis of Scientific Maps}

In this study, the creation and analysis of scientific maps are built by analysing the performance and productivity of sports nutrition publications using keyword co-occurrence analysis. In previous studies, author-selected keywords were widely used for indexing, information retrieval, bibliometrics, and knowledge organisation. For the extraction of the topics or themes, keywords with a frequency greater than or equal to 5 in the sample and a minimum frequency of keyword co-occurrence of 5 were chosen. Accordingly, a total of 12 clusters of the critical topics in Sports Nutrition were obtained. Table 4 lists the various clusters, the keywords, and the cluster's network that comprise them. It should be noted that this analysis enables the identification of common topics or themes that can be used to achieve the research lines related to the review's purpose and objectives. 


$\begin{array}{lll}\text { No. Cluster } & \text { Keywords } & \text { Cluster's Network }\end{array}$

$\begin{array}{ll} & \text { 1. Dietary-proteins } \\ & \text { 2. Cross-sectional study } \\ & \text { 3. Macronutrient } \\ & \text { 4. Trace-element } \\ & \text { 5. Vitamins } \\ & \text { 6. Nutrient } \\ \text { 1. Trace Element } & \text { 7. Fat } \\ & \text { 8. Dietary-fats } \\ & \text { 9. Minerals } \\ \text { 10. Australia } \\ \text { 11. Micronutrients } \\ \text { 12. Football-player }\end{array}$

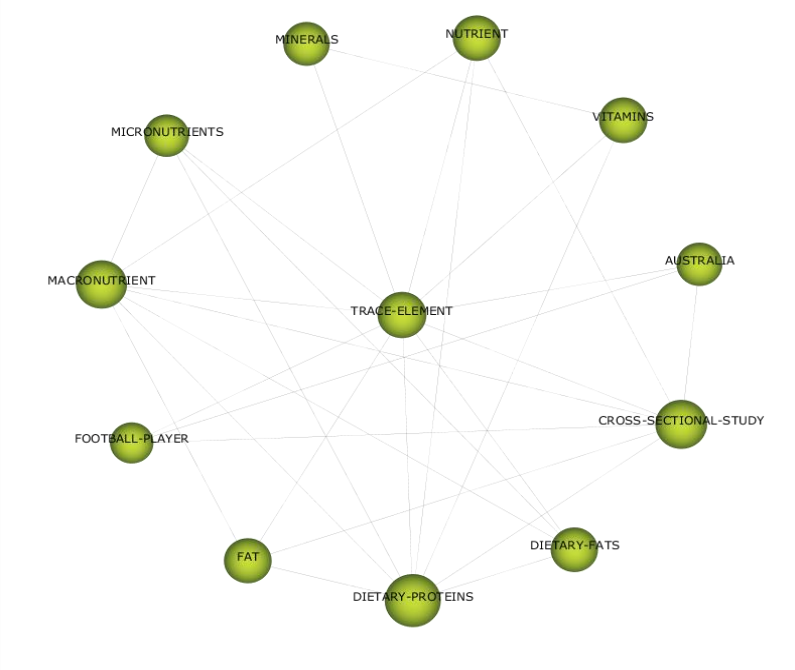

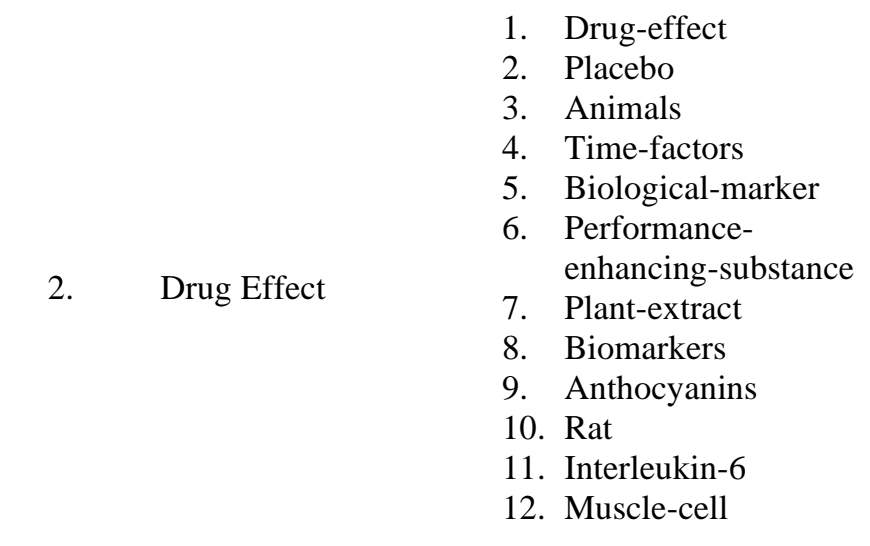

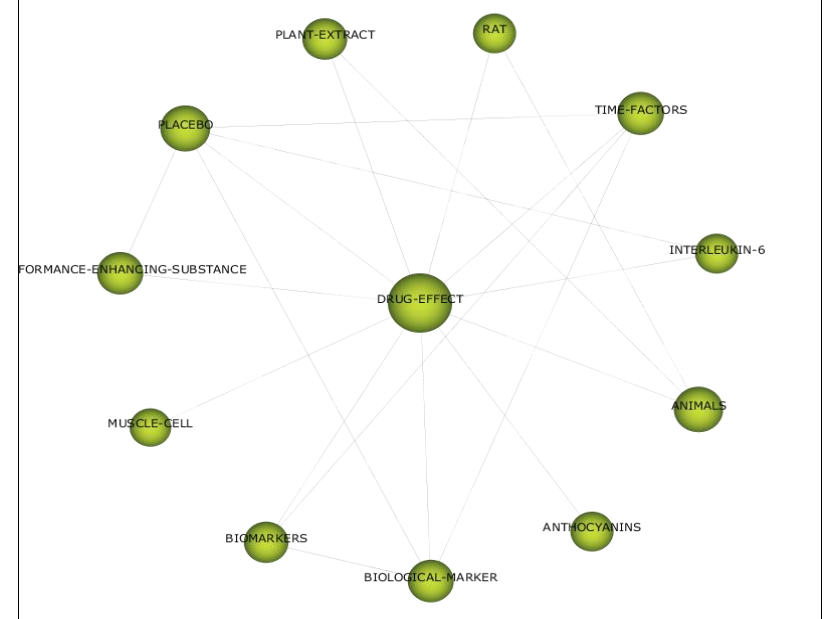

3. Questionnaire

1. Questionnaire

2. Aged

3. Sports-nutritionknowledge

4. Middle-aged

5. Attitude

6. Dietitian

7. Eating-habit

8. Food-preference

9. Nutritional-science

10. Runner

11. Sex-factors

12. Sports-nutritionalsciences

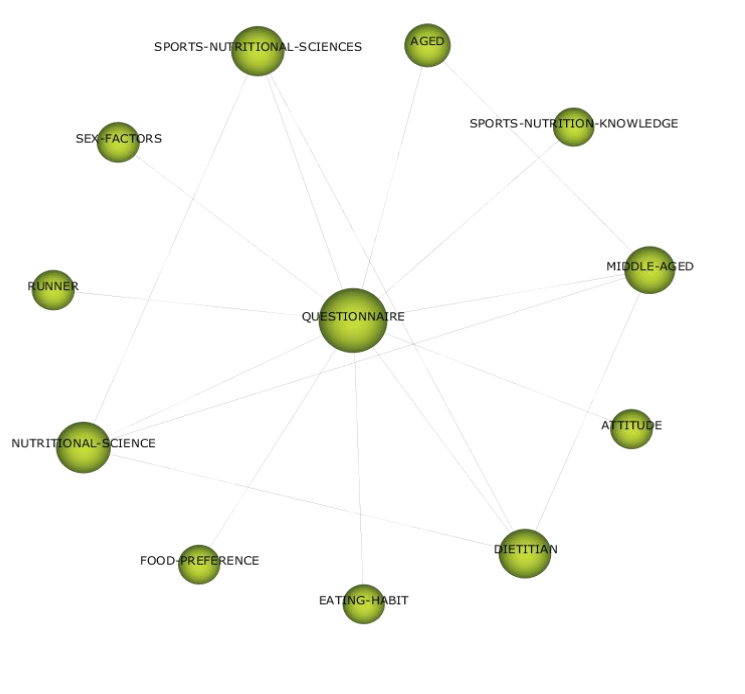


1. Adolescent

2. Team-sport

3. Vegetable

4. Young-adult

5. Anabolic-agent

6. Dietary-pattern

7. Eating-disorder

8. Endurance-sport

9. Hemoglobin

10. School

11. School-health-service

12. Sex-difference
1. Dietary-supplements

2. Nutritionalsupplements

3. Omega-fatty-acid

4. Weight-lifting

5. Branched-chainamino-acid

6. Ergogenic-aids

7. Fish-oil

8. Flavonoid

9. Glutathioneperoxidase

10. Immune-system

11. Nitrate

12. Nutritionalsupplement

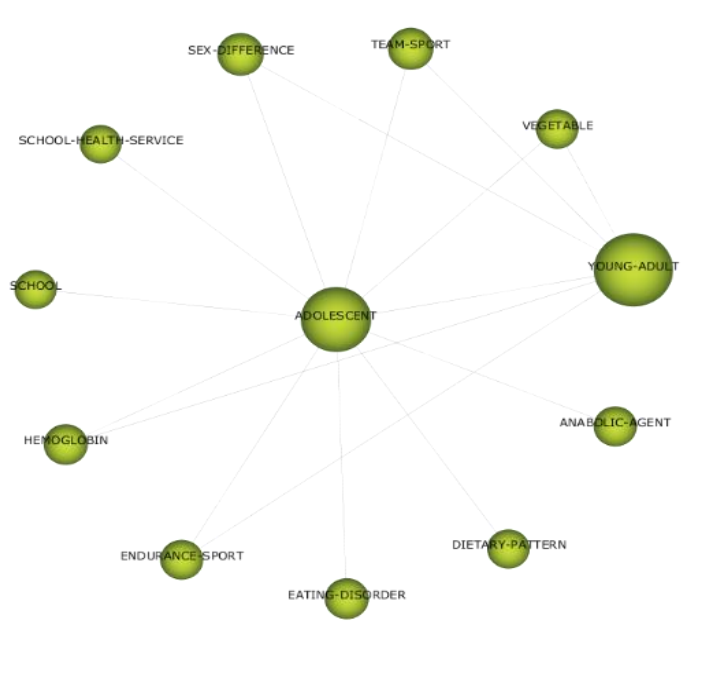

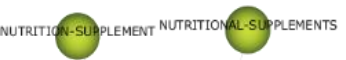
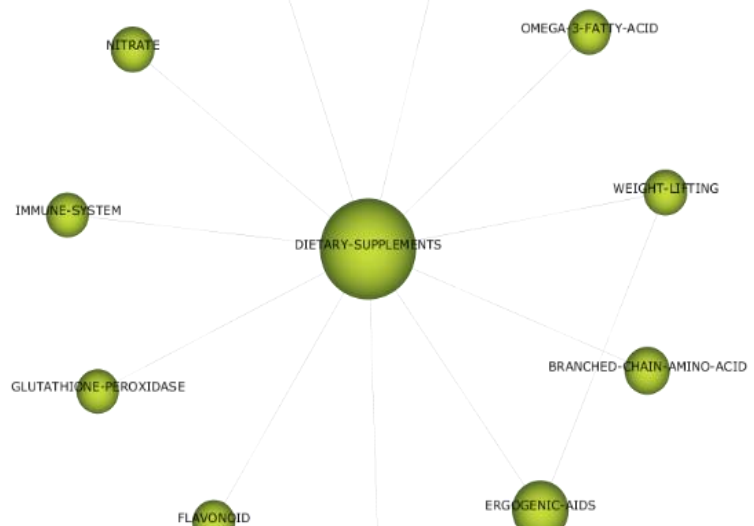

6. Athletes

1. Athlete

2. Season

3. University

4. Probiotic-agent

5. Coach

6. Energy-intake

7. Ferritin

8. Martial-arts

9. Nutritionists

10. Polysaturated-fattyacid

11. Reference-value

12. Meal 


$\begin{array}{ll}\text { 1. } & \text { Carbohydrate } \\ \text { 2. } & \text { Protein } \\ \text { 3. } & \text { Risk-factor } \\ \text { 4. } & \text { Glycemic-index } \\ \text { 5. } & \text { Body-fat } \\ \text { 6. } & \text { Dietary-intake } \\ \text { 7. } & \text { Electrolyte } \\ \text { 8. Endurance-athlete } \\ \text { 9. } \text { Carbohydrate } & \text { Fatty-acid } \\ \text { 10. Gastrointestinal- } & \text { symptom } \\ \text { 11. Lipid } \\ \text { 12. Nutritional- } \\ & \text { requirement }\end{array}$

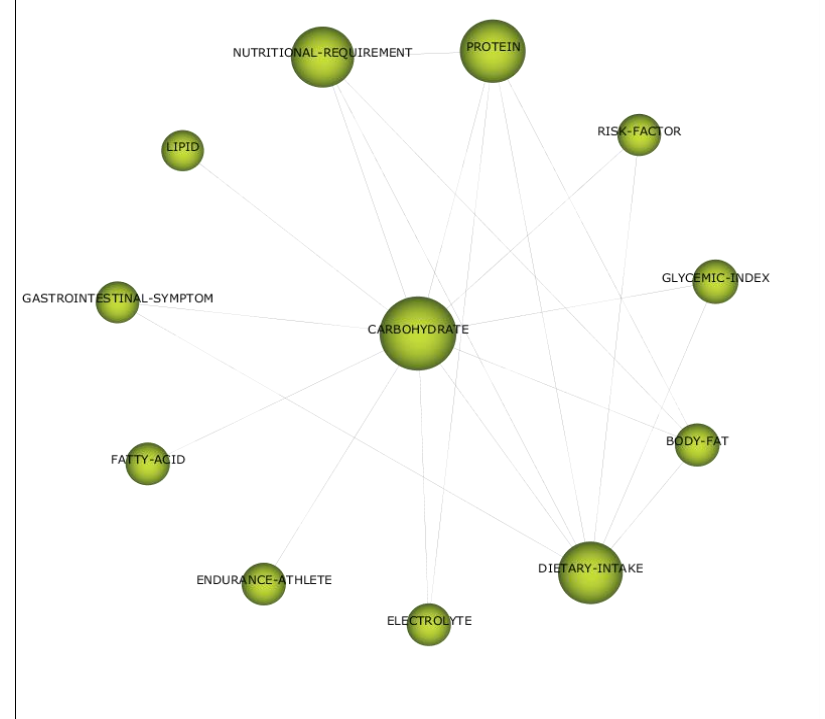

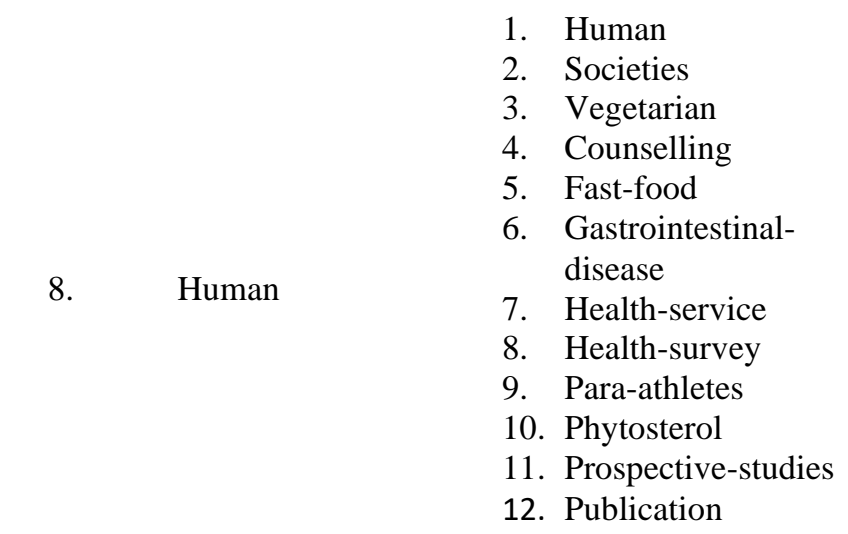

1. Male

2. Body-composition

3. Lifestyle

4. Concentration(parameters)

5. Beverage

9. Male

6. Comparative-study

7. Elite-athlete

8. Energy-drink

9. Feasibility-study

10. Injury

11. Students

12. Whey-protein

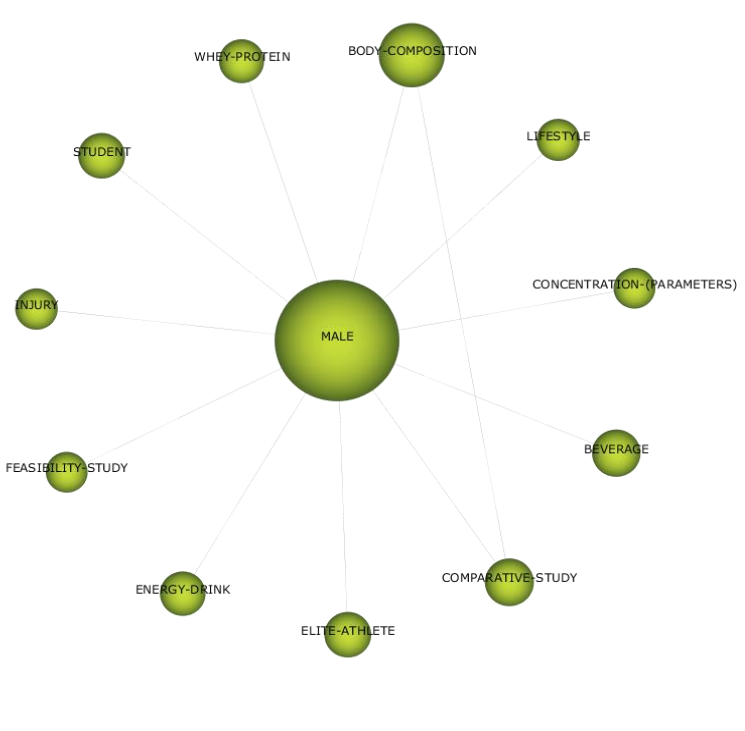




$\begin{array}{lll} & \text { 1. Sports-Nutrition } \\ & \text { 2. Survey } \\ & \text { 3. } & \text { Coffee } \\ & \text { 4. } & \text { Glucose-Transporter } \\ & \text { 5. Ergogenic } \\ & \text { 6. } \\ & \text { 7. Healthy-lifestyle } \\ \text { 10. Sports Nutrition } & \text { 8. } & \text { Recommendendations } \\ & \text { 9. Spinal-cord-injury } \\ & \text { 10. Sports-supplements } \\ & \text { 11. Strength-training } \\ & \text { 12. Supplements }\end{array}$

1. Exercise

2. Muscle-protein

3. Physical-activity

4. Polyphenols

5. Amino-acids

6. Antioxidant

11. Exercise 7. Bicarbonate

8. Casein

9. Diet

10. Essential-amino-acid

11. Ketogenic-diet

12. Muscle

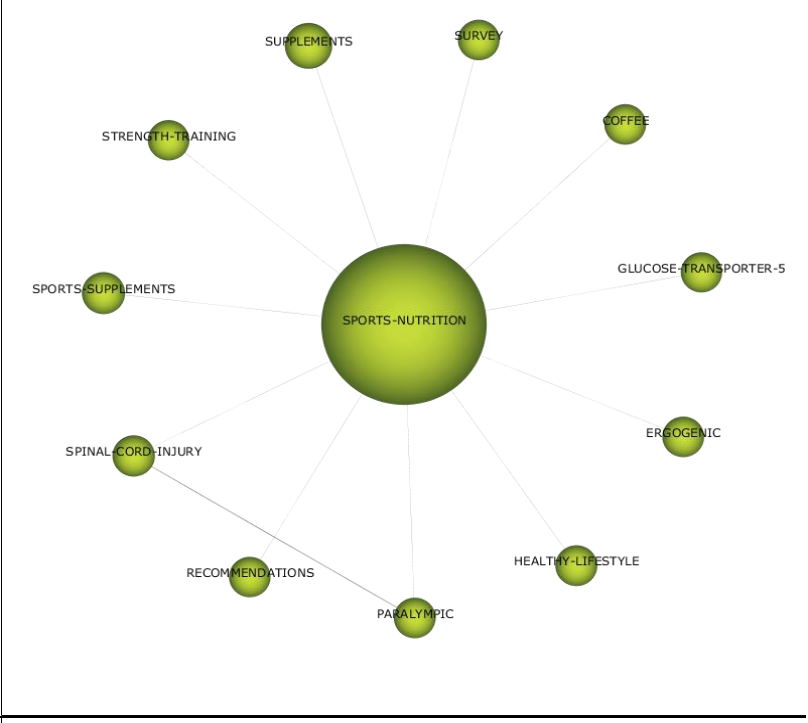

1. Sport

2. Standards

12. Sport

3. Nutrition-assessment

4. Sports-drink

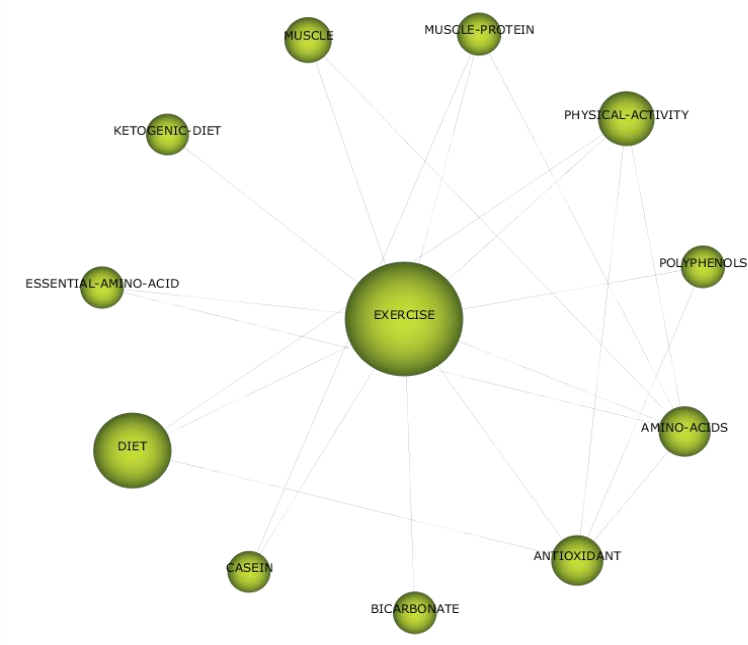


After extracting the main topics or themes in the sports nutrition research area, the authors analyse the various keywords extracted. The extracted keywords were also discussed along with the selected high impact-related articles nexus to the respective clusters. This section's information is based on the SciMAT report, which is shown below:

1. Trace Element: This cluster has a close relationship with keywords of dietary protein, cross-sectional study, and macronutrients. The top three highest impact articles related to this cluster were written by (Thomas et al., 2016), Kopp-Woodroffe et al. (1999), and Kerksick et al. (2017). Thomas et al. (2016) provide current dietary and hydration guidelines for active adults and competitive athletes. The sports dietitian can modify these broad guidelines to meet the specific demands of each athlete's body type, practical problems, and food preferences. Another article written by Kopp-Woodroffe et al. (1999) claimed that persistent energy deficiency is a significant factor contributing to exercise-induced menstruation disorder. In such circumstances, macronutrient and micronutrient intakes may be deficient as well. In terms of trace elements, Kerksick et al. (2017) stated that nutrition timing is a growing area of research that attracts the attention of researchers, coaches, and consumers. This is a critical issue because vitamins and trace elements are essential in sports and exercise. All nutrients that are involved in energy metabolism also play a role in physical performance.

2. Drug Effect: This cluster encompasses the drug-effect, placebo, and animals regarding sports nutrition. Kreider (2003), Campbell et al. (2006), and Dahlquist et al. (2015) were among the top three authors that published impact articles concerning the cluster of drug effects. Kreider (2003) discovered that creatine has grown in popularity among athletes and appears to be a generally effective nutritional ergogenic aid for various exercise tasks in diverse athletic and clinical populations. Campbell et al. (2006) found that l-arginine-ketoglutarate (AAKG) supplementation was safe and well-tolerated and improved one repetition maximum (1RM) bench press and Wingate peak power performance in trained adult men. A study published in 2015 by Dahlquist et al. examined the role of vitamin D in sports nutrition and how it might improve athletic performance. According to their findings, skeletal muscle has been found to have a high concentration of vitamin D receptors and vitamin D response factors.

3. Questionnaire: This cluster addresses the relationship between sports nutrition knowledge and nutritional science. The top three most impactful articles within this cluster were written by Jäger et al. (2017), Kerksick et al. (2018), and Aragon et al. (2017). According to Jäger et al. (2017), most scientific research on the effects of protein intake on exercise performance has focused on supplemental protein intake. The dependent measures of these studies can be divided into two categories: (i) endurance exercise performance and (ii) resistance exercise performance. Kerksick et al. (2018) revealed that hundreds of research papers are published annually in sports nutrition. A professional sports nutritionist's ability to evaluate the scientific merit of articles and advertisements about exercise and nutrition is critical. A review conducted by Aragon et al. (2017) stated several major diet types with numerous subtypes. As a result, the general public and practitioners may be confused by conflicting principles; the widespread media promotes unfounded fad diets (Aragon et al., 2017). Thus, a systematic review of scientific evidence is required to develop recommendations for healthcare providers, coaches, athletes, and the general public.

4. Adolescent: The most important keywords in this cluster are young-adult, adolescent, and sex difference. Goldberg et al. (1996) contributed to a more impactful article in this cluster. They studied a team-based educational intervention that reduces adolescent athletes' intent to use anabolic-androgenic steroids (AAS) is diminished by a team-based educational intervention. Goldberg et al. (1996) discovered that experimental subjects had a better understanding of AAS effects, greater belief in personal vulnerability to AAS effects, better drug refusal skills, less belief in AAS-promoting media messages, and more trust in the team as a source of information when compared to the control group. Elliot et al. (2004) contributed another significant article to this cluster. Elliot et al. (2004) concluded that sports teams are natural vehicles for gender-specific, peer-led curricula to promote healthy lifestyles and deter disordered eating, athletic-enhancing substance use, and other health-harming behaviours. 
5. Dietary Supplement: This cluster's primary goal is to analyse nutritional supplements to obtain optimal sports nutrition knowledge for athletes to manage a well-balanced diet. Nutritional supplements, ergogenic aids, and branched-chain amino acids are the three most prominent keywords in this cluster. Kreider et al. (1998) wrote the most impactful article with the highest number of citations in this cluster. The study aims to see how 28 days of creatine supplementation during training affects body composition, strength, sprint performance, and haematological profiles. Kreider et al. (1998) discovered that haematological parameters remained within normal clinical limits for active individuals with no reported side effects. After conducting a study, they found that supplementation with creatine increased fat and bone-free mass, isotonic lifting volume, and sprint performance during intense training.

6. Athletes: This cluster exposes the relationship between the keywords of athletes, energy intake, and meals. The most impactful article in this cluster was written by Thomas et al. (2016). The article discusses current recommendations for energy, nutrients, and fluids for active adults and competitive athletes. This article concluded that athletes must consume an adequate amount and timing of energy during periods of high-intensity or prolonged training to maintain health and optimise performance. Loucks et al. (2011) wrote another article that had an impact on this cluster. The article updates and complements the review of energy balance and body composition in the Proceedings of the 2003 International Olympic Committee Consensus Conference on Sports Nutrition, published in 2003. Athletes' diets can benefit more from considering energy availability rather than balance, according to this paper.

7. Carbohydrate: This cluster encompasses the point of view of athletes regarding sports nutrition and related keywords such as carbohydrate, protein, dietary intake, and nutritional requirement. Article written by Jeukendrup et al. (1999) obtained high citation in this cluster. According to Jeukendrup et al. (1999), blood glucose is a vital substrate during exercise. Exercise increases whole-body glucose turnover due to increases in muscle glucose uptake and endogenous glucose production. Another impactful study conducted by Durkalec-Michalski et al. (2018) indicates that high-carbohydrate and low-fat diets decreased fat oxidation. Also, they found that the 3-week moderate glycemic index (MGI) diet had increased carbohydrate oxidation rate during incremental cycling tests and had improved performance in acute intense exercise tests.

8. Human: Counselling, vegetarian, health survey, fast food, and health services are keywords in this cluster. It is quantified that in this cluster, athletes' knowledge of sports nutrition is critical. Rockwell et al. (2001) authored the most cited article in this cluster. According to the paper, coaches and trainers are knowledgeable about appropriate nutritional recommendations. Nonetheless, registered dietitians or qualified sports nutrition professionals may supplement athletes' nutrition-related education and counselling. According to Rogerson (2017), veganism is becoming more widely known due to the widespread use of social media as a means of disseminating information. Therefore, sports and the health and fitness industry may begin to accept it, among other places.

9. Male: This cluster comprises keywords such as body composition, comparative study, and beverage. The article written by Torres-McGehee et al. (2012) was among the most impactful papers in this cluster. In this research, athletes, coaches, athletic trainers, and conditioning specialists were asked to complete a questionnaire about nutrition knowledge. The findings indicated most coaches, athletic trainers, and conditioning specialists stated registered dietitians were their nutrition resources. Burke et al. (2017) concluded a significant increase in fat oxidation capacity during intense exercise. Also, the article had mentioned chronic adaptation to a ketogenic low-carbohydrate, high-fat diet impairs the exercise economy. It prevents the transfer of training-induced increased aerobic capacity to improve performance in a real-world endurance event in elite athletes.

10. Sports Nutrition: Under this cluster, the most related keywords are supplements, sports supplements, and healthy lifestyles. An article was written by Roberts et al. (2010) was among the top articles in this cluster. The paper examines the effects of carbohydrates alone or combined with caffeine on a rugby union-specific shuttle running protocol. Contrary to placebo and carbohydrate alone, they found that a moderate dose of caffeine co-ingested with carbohydrate improved high-intensity and sprint 
performance. Another impactful article written by Hirschbruch et al., (2008) highlighted that fitness centre concerns about physical appearance and aesthetics could lead to indiscriminate supplement use. They discovered that supplement use is widespread in fitness centres, where the environment encourages it.

11. Exercise: This topic analyses the influence of sports nutrition concerning exercise, with the most notable keywords being diet, physical activity, and antioxidant. The most impactful article under this cluster is written by Ha and Zemel (2003). The paper uses stable isotopes to show that whey proteins or similar amino acid mixtures promote whole-body and muscle protein synthesis. In addition to providing a substrate and bioactive components, whey proteins, composite amino acids, or associated compounds may also provide antioxidants. An article written by Maughan et al. (2007) was also being grouped under this cluster. The article concludes that all dietary supplements have potential costs, including the risk of a positive doping test due to undeclared prohibited substances.

12. Sport: The last cluster that has been found in this review is a sport. This cluster has placed the keywords such as sport-drinks, nutritional assessment, and standard. One of the most impactful articles under this cluster is written by Heaney et al. (2010). The purpose of this article is to compare strategies for determining the nutritional sufficiency of elite female athletes' dietary intake. They concluded that interpreting dietary adequacy is complicated and varies depending on whether the mean, the proportion of participants who fall below relevant nutrient reference values, or a statistical probability estimate of inadequacy is used. Additional research is required to determine dietary adequacy in athlete populations. In addition, Couture et al. (2015) reported that coaches' two most frequently recommended nutrition practices to enhance athlete performances were hydration and protein-rich food consumption. Nutritional supplement use was extraordinarily uncommon and was guided only by football coaches, a non-lean sport. The findings of this study indicate that coaches require education and training in sports nutrition.

After completing the analysis of clusters, compositions, networks, and related articles, the authors then describe the level of development of each of the resulting topics and their global importance in the research area. Table 5 summarises the centrality, which indicates the degree to which a matter interacts with the other issues, and the density, which reflects a theme's internal cohesiveness.

Table 5. Clusters Information

\begin{tabular}{|c|c|c|c|c|}
\hline Cluster & Centrality & $\begin{array}{c}\text { Centrality } \\
\text { Range }\end{array}$ & Density & Density range \\
\hline Trace-element & 4.48 & 1 & 1.56 & 1 \\
\hline Drug-effect & 2.46 & 0.42 & 1.16 & 0.92 \\
\hline Questionnaire & 3.67 & 0.5 & 0.6 & 0.67 \\
\hline Adolescent & 3.94 & 0.58 & 0.4 & 0.5 \\
\hline Dietary-supplements & 2.02 & 0.33 & 0.27 & 0.42 \\
\hline Athlete & 4.03 & 0.75 & 0.19 & 0.33 \\
\hline Carbohydrate & 4.08 & 0.83 & 0.43 & 0.58 \\
\hline Human & 1.64 & 0.17 & 0.12 & 0.17 \\
\hline Male & 4.27 & 0.92 & 0.15 & 0.25 \\
\hline Sports-nutrition & 1.33 & 0.08 & 0.73 & 0.83 \\
\hline Exercise & 3.97 & 0.67 & 0.62 & 0.75 \\
\hline Sport & 1.77 & 0.25 & 0.77 & 0.08 \\
\hline
\end{tabular}

Based on Table 5, the highest degree of interaction is trace-element, followed by male and carbohydrate. Regarding density, that study found that trace-element is the topic with the highest level of internal development, followed by drug-effect and sport. The themes are positioned according to their centrality and density in the strategic diagram shown in Figure 3. The number of documents associated with each topic is indicated by the size of the spheres in each cluster.

The topics most related to the rest and more developed, defined as driving issues grouped in the motor theme, are trace-element, exercise, questionnaire, carbohydrate, and adolescent. The most prominent for its 
positioning is trace-element. These topics are essential topics that allow the formation of a scientific field on sports nutrition publication for six decades. Regarding the transversal or fundamental issues, the case closely related to the rest, but underdeveloped, are athlete and male. The peripheral themes are those that are less central.

Figure 3 depicts two groups of more minor main themes. The first group consists of highly developed topics but have little in common with the others; in this case, this study identified two topics: sport-nutrition and drug-effect. They are distinct subjects in their own right; however, they have not been thoroughly examined concerning other issues. These are highly specialised topics. The topics or themes less developed in the second group are related to dietary supplements, human, and sport. They represent emerging or disappearing themes. In this case, these three themes are emerging themes within this study context.

Regarding evaluating the productivity and the impact of each topic in the current study, Table 6 displays the number of documents, the $\mathrm{H}$ index, and the number of citations for each topic or theme containing at least five keywords from the thematic network.

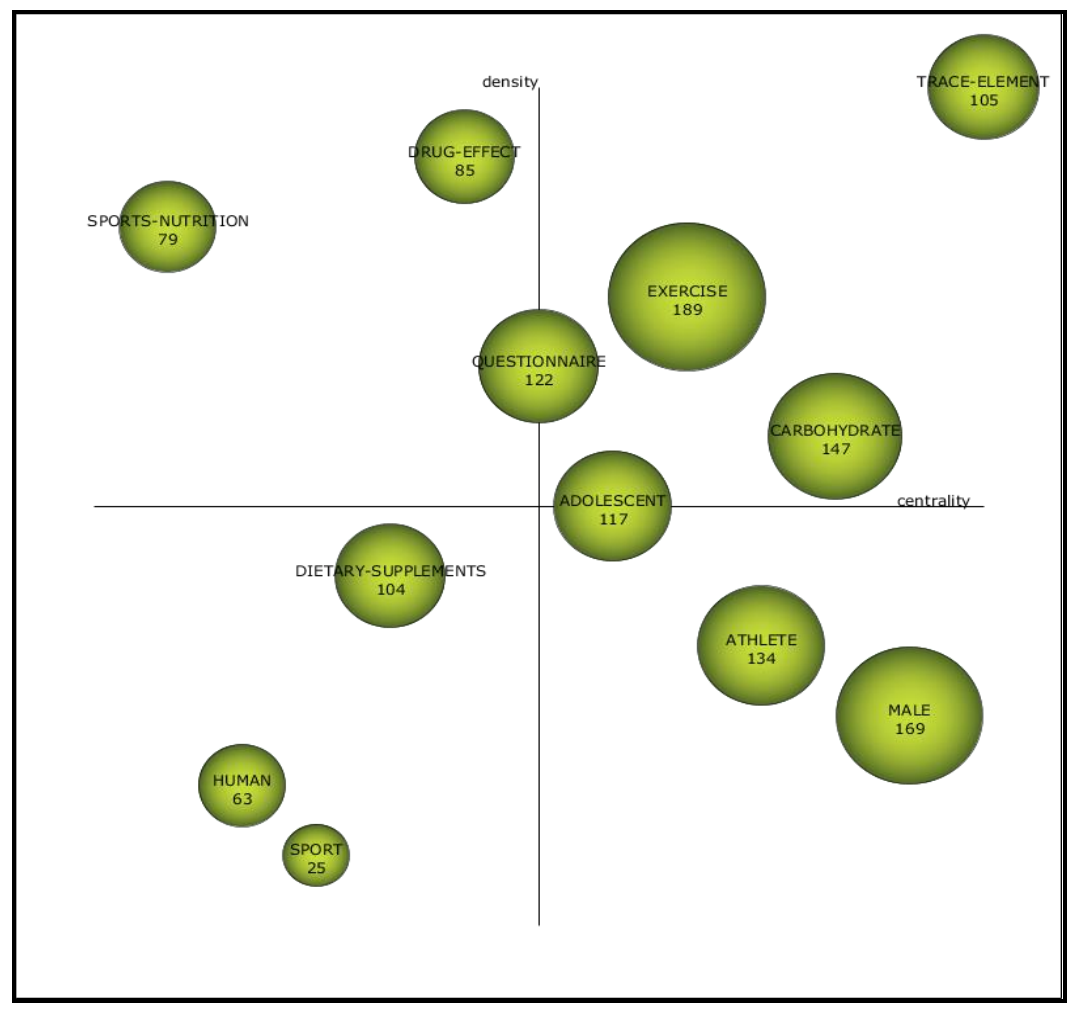

Figure 3. Strategic Diagram of Sports Nutrition Themes

Table 6. Productivity and Impact of Each Clusters

\begin{tabular}{cccc}
\hline Cluster & Documents Count & H-Index & Sum Citations \\
\hline Trace-element & 105 & 22 & 2007 \\
Drug-effect & 85 & 20 & 1373 \\
Questionnaire & 122 & 25 & 2266 \\
Adolescent & 117 & 26 & 1871 \\
Dietary-supplements & 104 & 28 & 3209 \\
Athlete & 134 & 30 & 2995 \\
Carbohydrate & 147 & 26 & 2230 \\
Human & 63 & 18 & 1361 \\
Male & 169 & 29 & 3174 \\
Sports-nutrition & 79 & 18 & 988 \\
Exercise & 189 & 34 & 4385 \\
Sport & 25 & 9 & 422 \\
\hline
\end{tabular}


Based on Table 6, exercise is the cluster with the highest number of documents (189) and with the highest H-index (34) as well as citations (4385). The clusters with the highest documents counted are exercise (189), male (169) and carbohydrate (147). In this study, the cluster with the highest H-index is exercise (34), athlete (30), and male (29). Regarding the number of citations, the first-ranked is still exercise (4385), followed by dietary-supplement (3209) and male (3174).

Sport (6), human (63) and sports-nutrition (79) were found to be the least productive clusters in terms of documents in the current study. In terms of a minor order based on the $\mathrm{H}$-index, this study discovered that sport (9) had the lowest H-index on the list, followed by human (18) and sports-nutrition (18), both of which had the same values. Finally, the total number of citations for sport (422) and sports nutrition (988) is less than 1000 .

\section{CONCLUSION}

The intellectual structure of sports nutrition in this study has been analysed using a bibliometric measure. The area's performance was analysed through the evolution of publication by years, highly cited papers and source titles. The scientific output was examined using a co-occurrence analysis of keywords with the aid of SciMAT software. The most pressing concerns in sports nutrition along these six decades have been recognised, along with their potential solutions.

The findings of this study show how the evolution of sports nutrition publications is progressing, with the number of publications increasing in recent years and reaching 175 in 2020 . Burke, L. M. stands out as an author with the most documents in terms of performance and production. He had published 97 publications related to sports nutrition. Also, this study showed that the International Journal of Sport Nutrition and Exercise Metabolism had been recognised as the most productive source's title. The article "Nutrition and Athletic Performance", published by Medicine and Science in Sports and Exercise in 2016, has been approved to be the most cited publication over six decades.

From the analysis of the co-occurrence of keywords, 12 main themes or clusters have been detected in the sports nutrition research area, which is: trace-element, drug-effect, questionnaire, adolescent, dietarysupplements, athlete, carbohydrate, human, male, sports-nutrition, exercise, and sport.

By considering the centrality and density of each theme in the strategic diagram, this study depicted that trace-element, exercise, questionnaire, and carbohydrate were positioned within the motor theme, which is a well-developed and essential theme in the research area. The specialised themes found in this study were sport-nutrition and drug-effect. Dietary supplements, human, and sport, represented emerging or disappearing themes. And lastly, the transversal or fundamental themes that are underdeveloped are athlete and male.

Through analysing the productivity and impact of each theme or cluster, the exercise provides the highest number of documents, with the highest $\mathrm{H}$-index and with the highest number of citations. The clusters with the most documents are exercise, male, and carbohydrate. As for the H-index, it would be exercise, athlete, and male. And, regarding the number of sum citations, this study found that exercise, dietary-supplement, and male were composed in the high sum citations assemblage.

Also, this study found that, in the area of sports nutrition, the most outstanding topics or themes have been delineated are: (i) trace-element, which has a close relationship with keywords of dietary protein, cross-sectional study, and macronutrients, (ii) exercise together with the most notable keywords such as diet, physical activity, and antioxidant were closely related to each other, (iii) carbohydrate concerning to the athletes' perspective on sports nutrition and includes the terms protein, dietary intake, and nutritional requirement, (iv) questionnaire, which examines the association between knowledge of sports nutrition and nutritional science, and (v) adolescent, with the primary keywords being young adult, adolescent, and sex difference.

Finally, there are several limitations to this study. The first is the researchers' interpretation of the topics or themes based on their knowledge. Another significant constraint is the researchers' choices of data metrics and clustering techniques; alternative measures could result in different scientific maps. Due to the study's reliance on a single Scopus database citation database, publications discovered in other databases 
were excluded, influencing the study's findings. Thus, the subject area may have changed if additional databases such as Google Scholar, Microsoft Academics, or Dimensions were retrieved.

As future lines of research in sports nutrition, conducting the study using additional databases will allow for the expansion of the field of knowledge about sports nutrition and the incorporation of other disciplines of application of this term. Sports nutrition is a rapidly growing topic, with hundreds of research papers released annually in the current year, making study into the discipline challenges. Moreover, based on the findings, the following study themes emerge as the most compelling in this field were trace element, exercise, carbohydrate, questionnaire, and adolescent. Thus, future research should focus more closely on these themes via a systematic literature review or narrative review to better understand the correlation between those themes in sports nutrition research.

\section{ACKNOWLEDGEMENTS}

The authors express their gratitude to the reviewers. The assessment carried out by the reviewers has helped this writing in attaining the required academic standard. Also, the reviewers' insightful comments and opinions assisted future readers and researchers refine the writing's content.

\section{CONFLICT OF INTEREST}

The Author declared that there are no conflict of interest in writing this article.

\section{REFERENCES}

Aljaloud, S. O., \& Ibrahim, S. A. (2013). Use of dietary supplements among professional athletes in Saudi Arabia. Journal of Nutrition and Metabolism, 2013. https://doi.org/10.1155/2013/245349

Amatori, S., Sisti, D., Perroni, F., Impey, S., Lantignotti, M., Gervasi, M., Zeppa, S. D., \& Rocchi, M. B. L. (2020). Which are the nutritional supplements used by beach-volleyball athletes? A cross-sectional study at the Italian national championship. Sports, 8(3), 4-15. https://doi.org/10.3390/sports8030031

Aragon, A. A., Schoenfeld, B. J., Wildman, R., Kleiner, S., VanDusseldorp, T., Taylor, L., Earnest, C. P., Arciero, P. J., Wilborn, C., Kalman, D. S., Stout, J. R., Willoughby, D. S., Campbell, B., Arent, S. M., Bannock, L., Smith-Ryan, A. E., \& Antonio, J. (2017). International society of sports nutrition position stand: Diets and body composition. Journal of the International Society of Sports Nutrition, 14(1), 119. https://doi.org/10.1186/s12970-017-0174-y

Arenas-Jal, M., Suñé-Negre, J. M., Pérez-Lozano, P., \& García-Montoya, E. (2020). Trends in the food and sports nutrition industry: A review. Critical Reviews in Food Science and Nutrition, 60(14), 24052421. https://doi.org/10.1080/10408398.2019.1643287

Bailey, R. L., Gahche, J. J., Lentino, C. V., Dwyer, J. T., Engel, J. S., Thomas, P. R., ... \& Picciano, M. F. (2011). Dietary supplement use in the United States, 2003-2006. The Journal of nutrition, 141(2), 261266. https://doi.org/10.3945/jn.110.133025

Burke, L. M, \& Read, R. S. D. (1989). Sports Nutrition: Approaching the Nineties. Sports Medicine, 8(2), 80-100. https://doi.org/10.2165/00007256-198908020-00002

Burke, L. M., \& King, C. (2012). Ramadan fasting and the goals of sports nutrition around exercise. Journal of Sports Sciences, 30(SUPPL.1), 37-41. https://doi.org/10.1080/02640414.2012.680484

Burke, L. M., Ross, M. L., Garvican-Lewis, L. A., Welvaert, M., Heikura, I. A., Forbes, S. G., Mirtschin, J. G., Cato, L. E., Strobel, N., Sharma, A. P., \& Hawley, J. A. (2017). Low carbohydrate, high fat diet impairs exercise economy and negates the performance benefit from intensified training in elite race walkers. Journal of Physiology, 595(9), 2785-2807. https://doi.org/10.1113/JP273230

Burke, L. M, Cort, M., Cox, G., Crawford, R., Desbrow, B., Farthing, L., Minehan, M., Shaw, N., \& Warnes, O. (2006). Supplements and sports foods. Clinical Sports Nutrition, 3, 485-580. 
Campbell, B., Roberts, M., Kerksick, C., Wilborn, C., Marcello, B., Taylor, L., Nassar, E., Leutholtz, B., Bowden, R., Rasmussen, C., Greenwood, M., \& Kreider, R. (2006). Pharmacokinetics, safety, and effects on exercise performance of l-arginine $\alpha$-ketoglutarate in trained adult men. Nutrition, 22(9), 872-881. https://doi.org/10.1016/j.nut.2006.06.003

Ciomaga, B. (2013). Sport management: A bibliometric study on central themes and trends. European Sport Management Quarterly, 13(5), 557-578. https://doi.org/10.1080/16184742.2013.838283

Cobo, M. J., Lopez-Herrera, A. G., Herrera-Viedma, E., \& Herera, F. (2011). Science Mapping Software Tools: Review, Analysis, and Cooperative Study Among Tools. Journal of the American Society for Information Science and Technology, 62(7), 1382-1402. https://doi.org/10.1002/asi

Cobo, M. J., Lopez-Herrera, A. G., Herrera-Viedma, E., \& Herera, F. (2012). SciMAT: A New Science Mapping Analysis Software Tool M.J. Journal of the American Society for Information Science and Technology, 64, 1852-1863. https://doi.org/10.1002/asi.22688

Couture, S., Lamarche, B., Morissette, E., Provencher, V., Valois, P., Goulet, C., \& Drapeau, V. (2015). Evaluation of sports nutrition knowledge and recommendations among high school coaches. International Journal of Sport Nutrition and Exercise Metabolism, 25(4), 326-334. https://doi.org/10.1123/ijsnem.2014-0195

Dahlquist, D. T., Dieter, B. P., \& Koehle, M. S. (2015). Plausible ergogenic effects of vitamin D on athletic performance and recovery. Journal of the International Society of Sports Nutrition, 12(1), 1-12. https://doi.org/10.1186/s12970-015-0093-8

Devlin, B. L., \& Belski, R. (2015). Exploring general and sports nutrition and food knowledge in elite male australian athletes. International Journal of Sport Nutrition and Exercise Metabolism, 25(3), 225-232. https://doi.org/10.1123/ijsnem.2013-0259

Durkalec-Michalski, K., Zawieja, E. E., Zawieja, B. E., Podgórski, T., Jurkowska, D., \& Jeszka, J. (2018). Influence of low versus moderate glycemic index of diet on substrate oxidation and energy expenditure during incremental exercise in endurance athletes: a randomised counterbalanced cross-over trial. International Journal of Food Sciences and Nutrition, 69(6), 741-752. https://doi.org/10.1080/09637486.2017.1411891

Elliot, D. L., Goldberg, L., Moe, E. L., DeFrancesco, C. A., Durham, M. B., \& Hix-Small, H. (2004). Preventing Substance Use and Disordered Eating. Archives of Pediatrics \& Adolescent Medicine, 158(11), 1043. https://doi.org/10.1001/archpedi.158.11.1043

Fennell, D. (2004). Determinants of supplement usage. Preventive Medicine, 39(5), 932-939. https://doi.org/10.1016/j.ypmed.2004.03.031

Ferreira, J. J., Fernandes, C., Ratten, V., \& Miragaia, D. (2020). Sports innovation: A bibliometric study. In Sport entrepreneurship and public policy (pp. 153-170). Springer, Cham. https://doi.org/10.1007/978-3-030-29458-8_10

Gavrilova, N., Chernopolskaya, N., Rebezov, M., Schetinina, E., Suyazova, I., Safronov, S., Ivanova, V., \& Sultanova, E. (2020). Development of specialised food products for nutrition of sportsmen. Journal of Critical Reviews, 7(4), 233-236. https://doi.org/10.31838/jcr.07.04.43

Gazali, N., Cendra, R., Saputra, H. D., Saad, N. B., Winarno, M. E., Hanief, Y. N., ... \& Tulyakul, S. (2021). Trends and patterns of 2013 curriculum research in physical education: Bibliometric analysis from 2013-2020. Multilateral: Jurnal Pendidikan Jasmani dan Olahraga,20(3), 179-199. http://dx.doi.org/10.20527/multilateral.v20i3.11656 
Goldberg, L., Elliot, D., Clarke, G. N., MacKinnon, D. P., Moe, E., Zoref, L., Green, C., Wolf, S. L., Greffrath, E., Miller, D. J., \& Lapin, A. (1996). Effects of a multidimensional anabolic steroid prevention intervention: The adolescents training and learning to avoid steroids (ATLAS) program. Journal of the American Medical Association, 276(19), 1555-1562. https://doi.org/10.1001/jama.276.19.1555

Guest, N. S., Horne, J., Vanderhout, S. M., \& El-Sohemy, A. (2019). Sport nutrigenomics: Personalised nutrition for athletic performance. Frontiers in Nutrition, 6. https://doi.org/10.3389/fnut.2019.00008

Ha, E., \& Zemel, M. B. (2003). Functional properties of whey, whey components, and essential amino acids: Mechanisms underlying health benefits for active people (Review). Journal of Nutritional Biochemistry, 14(5), 251-258. https://doi.org/10.1016/S0955-2863(03)00030-5

Hanief, Y. N., Kardiyanto, D. W., Winarno, M. E., \& Haqiyah, A. (2021). Development of Indonesia scientific publications of physical education in reputable international journals: A Bibliometric Analysis. Jurnal Pendidikan Jasmani dan Olahraga, 6(1), 59-67. https://doi.org/10.17509/jpjo.v6i1.32335

Heaney, S., O’Connor, H., Gifford, J., \& Naughton, G. (2010). Comparison of strategies for assessing nutritional adequacy in elite female athletes' dietary intake. International Journal of Sport Nutrition and Exercise Metabolism, 20(3), 245-256. https://doi.org/10.1123/ijsnem.20.3.245

Hirschbruch, M. D., Fisberg, M., \& Mochizuki, L. (2008). Consumo de suplementos por jovens freqüentadores de academias de ginástica em São Paulo. Revista Brasileira de Medicina Do Esporte, 14(6), 539-543. https://doi.org/10.1590/s1517-86922008000600013

Jäger, R., Kerksick, C. M., Campbell, B. I., Cribb, P. J., Wells, S. D., Skwiat, T. M., Purpura, M., Ziegenfuss, T. N., Ferrando, A. A., Arent, S. M., Smith-Ryan, A. E., Stout, J. R., Arciero, P. J., Ormsbee, M. J., Taylor, L. W., Wilborn, C. D., Kalman, D. S., Kreider, R. B., Willoughby, D. S., ... Antonio, J. (2017). International Society of Sports Nutrition Position Stand: Protein and exercise. Journal of the International Society of Sports Nutrition, 14(1), 1-25. https://doi.org/10.1186/s12970017-0177-8

Jeukendrup, A. E., Wagenmakers, A. J. M., Stegen, J. H. C. H., Gijsen, A. P., Brouns, F., \& Saris, W. H. M. (1999). Carbohydrate ingestion can completely suppress endogenous glucose production during exercise. American Journal of Physiology - Endocrinology and Metabolism, $276(4$ 39-4). https://doi.org/10.1152/ajpendo.1999.276.4.e672

Jiménez-García, M., Ruiz-Chico, J., Peña-Sánchez, A. R., \& López-Sánchez, J. A. (2020). A bibliometric analysis of sports tourism and sustainability (2002-2019). Sustainability (Switzerland), 12(7), 1-18. https://doi.org/10.3390/su12072840

Kaur, A., \& Nat, A. P. (2016). An Empirical Study on Consumption Behaviour of Sports Nutrition Products Among Wrestlers. International Journal of Fitness \& Exercise Science, 5, 1-10.

Kerksick, C. M., Arent, S., Schoenfeld, B. J., Stout, J. R., Campbell, B., Wilborn, C. D., Taylor, L., Kalman, D., Smith-Ryan, A. E., Kreider, R. B., Willoughby, D., Arciero, P. J., VanDusseldorp, T. A., Ormsbee, M. J., Wildman, R., Greenwood, M., Ziegenfuss, T. N., Aragon, A. A., \& Antonio, J. (2017). International society of sports nutrition position stand: Nutrient timing. Journal of the International Society of Sports Nutrition, 14(1), 1-21. https://doi.org/10.1186/s12970-017-0189-4

Kerksick, C. M., Wilborn, C. D., Roberts, M. D., Smith-Ryan, A., Kleiner, S. M., Jäger, R., Collins, R., Cooke, M., Davis, J. N., Galvan, E., Greenwood, M., Lowery, L. M., Wildman, R., Antonio, J., \& Kreider, R. B. (2018). Exercise \& sports nutrition review update: Research \& recommend. Journal of the International Society of Sports Nutrition, 15(1), 1-57. 
Kiss, A., Temesi, Á., Tompa, O., Lakner, Z., \& Soós, S. (2021). Structure and trends of international sport nutrition research between 2000 and 2018: bibliometric mapping of sport nutrition science. Journal of the International Society of Sports Nutrition, 18(1), 1-17. https://doi.org/10.1186/s12970-021-00409-5

Kopp-Woodroffe, S. A., Manore, M. M., Dueck, C. A., Skinner, J. S., \& Matt, K. S. (1999). Energy and nutrient status of amenorrheic athletes participating in a diet and exercise training intervention program. International Journal of Sport Nutrition and Exercise Metabolism, 9(1), 70-88. https://doi.org/10.1123/ijsn.9.1.70

Kreider, R. B. (2003). Effects of creatine supplementation on performance and training adaptations. Molecular and Cellular Biochemistry, 244(1-2), 89-94. https://doi.org/10.1023/A:1022465203458

Kreider, R. B., Ferreira, M., Wilson, M., Grindstaff, P., Plisk, S., Reinardy, J., Cantler, E., \& Almada, A. L. (1998). Effects of creatine supplementation on body composition, strength, and sprint performance. Medicine and Science in Sports and Exercise, 30(1), 73-82. https://doi.org/10.1097/00005768199801000-00011

Lindahl, J., Stenling, A., Lindwall, M., \& Colliandera, C. (2015). Trends and knowledge base in sport and exercise psychology research: A bibliometric review study. International Review of Sport and Exercise Psychology, 8(1), 71-94. https://doi.org/10.1080/1750984X.2015.1019540

Loucks, A. B., Kiens, B., \& Wright, H. H. (2011). Energy availability in athletes. Journal of Sports Sciences, 29(SUPPL. 1), 37-41. https://doi.org/10.1080/02640414.2011.588958

Maughan, R. J., Depiesse, F., \& Geyer, H. (2007). The use of dietary supplements by athletes. Journal of Sports Sciences, 25(SUPPL. 1), 103-113. https://doi.org/10.1080/02640410701607395

Mazzeo, F., Motti, M. L., Messina, G., Monda, V., Ascione, A., Tafuri, D., Palmieri, F., Messina, A., \& Monda, M. (2013). Use of nutritional supplements among south Italian students of physical training and sport university. Current Topics in Toxicology, 9(January), 21-26.

Miyaki, M., \& Okajima, Y. (2018). Do external funding sources affect research productivity?: A departmental-level analysis of seven former imperial Japanese universities. Munich Personal RePEc Archive, 88931, 1-27.

Moher, D., Liberati, A., Tetzlaff, J., \& Altman, D. G. (2009). Preferred reporting items for systematic reviews and meta-analyses: the PRISMA statement. Journal of Clinical Epidemiology, 62(10), 10061012. https://doi.org/10.1016/j.jclinepi.2009.06.005

Molinero, O., \& Márquez, S. (2009). Revisión use in sports: Risks, knowledge, and behavioural-related factors. Nutricion Hospitalaria, 24(2), 128-134.

Nunes, C. L., Matias, C. N., Santos, D. A., Morgado, J. P., Monteiro, C. P., Sousa, M., Minderico, C. S., Rocha, P. M., St-Onge, M. P., Sardinha, L. B., \& Silva, A. M. (2018). Characterisation and comparison of nutritional intake between preparatory and competitive phase of highly trained athletes. Medicina (Lithuania), 54(3). https://doi.org/10.3390/medicina54030041

Paule-Vianez, J., Gómez-Martínez, R., \& Prado-Román, C. (2020). A bibliometric analysis of behavioural finance with mapping analysis tools. European Research on Management and Business Economics, 26(2), 71-77. https://doi.org/10.1016/j.iedeen.2020.01.001

Potgieter, S. (2013). Sport nutrition: A review of the latest guidelines for exercise and sport nutrition from the American College of Sport Nutrition, the International Olympic Committee and the International Society for Sports Nutrition. South African Journal of Clinical Nutrition, 26(1), 6-16. https://doi.org/10.1080/16070658.2013.11734434 
Ravindra, P. V., Janhavi, P., Divyashree, S., \& Muthukumar, S. P. (2020). Nutritional interventions for improving the endurance performance in athletes. Archives of Physiology and Biochemistry, 0(0), 1-8. https://doi.org/10.1080/13813455.2020.1733025

Roberts, S. P., Stokes, K. A., Trewartha, G., Doyle, J., Hogben, P., \& Thompson, D. (2010). Effects of carbohydrate and caffeine ingestion on performance during a rugby union simulation protocol. Journal of Sports Sciences, 28(8), 833-842. https://doi.org/10.1080/02640414.2010.484069

Rockwell, M. S., Nickols-Richardson, S. M., \& Thye, F. W. (2001). Nutrition knowledge, opinions, and practices of coaches and athletic trainers at a Division I University. International Journal of Sport Nutrition, 11(2), 174-185. https://doi.org/10.1123/ijsnem.11.2.174

Rogerson, D. (2017). Vegan diets: Practical advice for athletes and exercisers. Journal of the International Society of Sports Nutrition, 14(1), 1-15. https://doi.org/10.1186/s12970-017-0192-9

Santos, J. M. S., \& García, P. C. (2011). A bibliometric analysis of sports economics research. International Journal of Sport Finance, 6(3), 222-244.

Thomas, D. T., Erdman, K. A., \& Burke, L. M. (2016). Nutrition and Athletic Performance. Medicine and Science in Sports and Exercise, 48(3), 543-568. https://doi.org/10.1249/MSS.0000000000000852

Torres-McGehee, T. M., Pritchett, K. L., Zippel, D., Minton, D. M., Cellamare, A., \& Sibilia, M. (2012). Sports Nutrition Knowledge Among Collegiate Athletes, Coaches, Athletic Trainers, and Strength and Conditioning Specialists. Journal of Athletic Training, 47(2), 205-211. 